G188(P) COULD VIDEO CALLING BE USED FOR EDUCATIONAL SUPERVISION MEETINGS? A SURVEY OF PAEDIATRIC TRAINEES AND TRAINERS WITHIN A SINGLE DEANERY

${ }^{1} \mathrm{~L}$ Stoddart, ${ }^{2} Y$ Tse, ${ }^{1} \mathrm{P}$ Kumar. 'General Paediatric Department, South Tyneside and Sunderland NHS FT, Sunderland, UK; ${ }^{2}$ Paediatric Nephrology Department, Great North Children's Hospital, Newcastle upon Tyne, UK

\subsection{6/archdischild-2020-rcpch.158}

Aim Surveying paediatric trainees' and trainers' opinions on potential use of video calling (VC) for educational supervision meetings.

Method Online survey of paediatric trainees and trainers in one region.

Results 33 trainees and 55 trainers responded. The majority had some experience of VC however 21.2\% of trainees and $29.1 \%$ of trainers had never used VC in any context. Applications that respondents had used included WhatsApp, Facetime and Skype. Further quantitative results are shown in table 1 . Free text identified 5 themes including comments related to privacy and confidentiality, IT infrastructure and cyber security, value of face to face meetings, potential benefits of $\mathrm{VC}$ and use of phone calls rather than video calls.

\begin{tabular}{|c|c|c|}
\hline & $\begin{array}{l}\text { Trainee } \\
\text { Responses } \\
(\%)\end{array}$ & $\begin{array}{l}\text { Trainer } \\
\text { Responses } \\
(\%)\end{array}$ \\
\hline $\begin{array}{l}\text { Do you feel the concept of using VC may be useful for } \\
\text { supervision meetings? }\end{array}$ & $\begin{array}{l}\text { Yes } 54.5 \\
\text { No } 18.2 \\
\text { Maybe } 27.3\end{array}$ & $\begin{array}{l}\text { Yes } 54.5 \\
\text { No } 7.3 \\
\text { Maybe } 38.2\end{array}$ \\
\hline $\begin{array}{l}\text { If given the choice to use VC for educational } \\
\text { supervision meetings, will you accept it? }\end{array}$ & $\begin{array}{l}\text { Yes } 36.4 \\
\text { No } 15.1 \\
\text { Sometimes } \\
48.5\end{array}$ & $\begin{array}{l}\text { Yes } 45.5 \\
\text { No } 12.7 \\
\text { Sometimes } \\
41.8\end{array}$ \\
\hline $\begin{array}{l}\text { Should face to face follow up meetings occur if the } \\
\text { need is identified in the VC meeting? }\end{array}$ & Yes 100 & Yes 100 \\
\hline Should VC meetings be allowed in non working time? & Yes 78.8 & Yes 56.4 \\
\hline $\begin{array}{l}\text { Do you think VC will improve training by avoiding } \\
\text { unnecessary time wasted in travel? }\end{array}$ & Yes 81.3 & Yes 79.6 \\
\hline $\begin{array}{l}\text { Do you see any issues related to confidentiality in using } \\
\text { VC for meetings? }\end{array}$ & Yes 30.3 & Yes 50.9 \\
\hline
\end{tabular}

Conclusion In this current era respondents had mixed views concerning use of $\mathrm{VC}$ and felt it can be an optional additional tool. Respondents raised concerns that VC may lose the value of face to face meetings in developing rapport, providing feedback and pastoral care. Concerns about practical implementation such as IT infrastructure and cyber security will need to be addressed. Next step will be to pilot and test VC for educational supervision meetings.

\section{G189(P) QUIZ TIME! A PAEDIATRIC LEARNING PROJECT}

${ }^{1} \mathrm{LC}$ Yarlott, ${ }^{2} \mathrm{C}$ Singh. ${ }^{1}$ Paediatrics, Royal London Hospital, London, UK; ${ }^{2}$ Paediatrics, North Middlesex Hospital, London, UK

10.1136/archdischild-2020-rcpch.159
Background A commitment to postgraduate learning is an essential part of a career in paediatrics. Classically, this involves minimal peer interaction and a focus on home study. Creative education methods are well recognised in schools and universities, but postgraduate medical education remains largely traditional and self-directed.

Here we present the results of a series of paediatric quizzes for doctors of all levels. 'Gamification' (the application of elements of game playing to other activities e.g. learning) is a proven method of incentivisation and is used across multiple industries to create engagement and motivation, as well as fostering teamwork and a sense of working together towards a common goal.

Aims

- To demonstrate that an educational quiz creates a positive, enjoyable learning environment

- To demonstrate value for quiz participants in terms of learning outcomes

- To produce a scalable learning activity framework that can be recreated across departments and sites

Methods and Results Quiz participants were interviewed and took a questionnaire pre and post activity. Reasons for participating were cited as learning (75\%), supporting colleagues $(100 \%)$ and having fun $(87.5 \%)$. Opinions about learning and learning styles were sought prior to the activity, with the most striking findings being that $62.5 \%$ of the participants found learning to be lonely, $50 \%$ said it felt like a chore, and $75 \%$ found it difficult to find the motivation to learn. $75 \%$ preferred to learn with others and $75 \%$ preferred to learn in a group setting, and $100 \%$ felt that games and quizzes helped their learning.

Following the activity $87.5 \%$ reported feeling positive about this way of learning, $87.5 \%$ said it did not feel like a chore, and $62.5 \%$ said it made them feel more motivated to learn. $75 \%$ reported feeling less lonely whilst learning and 100\% would attend again. 100\% had fun, and 100\% reported learning something new.

Following the success of this first arm of the pan London paediatric quiz project, we plan to extend the invitation to other Trusts. We are hopeful that this will instil both a sense of friendly competition, augment individual study, and develop a sense of community across London paediatric hospitals.

\section{G190(P) PED TALKS: PAEDIATRICIANS EDUCATING AND DEVELOPING TOGETHER}

KA Evans, K Lydekker, R Roots, N Prince. Department of Paediatrics, St Georges University Hospitals NHS FT, London, UK

\subsection{6/archdischild-2020-rcpch. 160}

Aims Working within a tertiary hospital with multiple paediatric teams can make it difficult for paediatric trainees to attend teaching sessions during the day The GMC has emphasised the importance of institutions' duty to foster an environment of learning. We therefore set out to create an innovative teaching programme that would bring these teams together in an informal educational setting with the opportunity to meet other members of the MDT.

Methods In September 2018, the paediatric team devised a plan to make paediatric themes accessible to the wider MDT. This was achieved through quarterly teaching sessions 